\title{
Paideusis
}

\section{"Talking About Feelings and Values with Children" (Michael Schleifer (with Cynthia Martiny))}

Thomas Falkenberg

Volume 15, Number 2, 2006

URI: https://id.erudit.org/iderudit/1072684ar

DOI: https://doi.org/10.7202/1072684ar

See table of contents

Publisher(s)

Canadian Philosophy of Education Society

ISSN

0838-4517 (print)

1916-0348 (digital)

Explore this journal

Cite this review

Falkenberg, T. (2006). Review of ["Talking About Feelings and Values with Children" (Michael Schleifer (with Cynthia Martiny))]. Paideusis, 15(2), 101-106. https://doi.org/10.7202/1072684ar

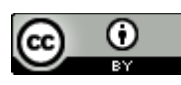

This document is protected by copyright law. Use of the services of Erudit (including reproduction) is subject to its terms and conditions, which can be viewed online.

https://apropos.erudit.org/en/users/policy-on-use/ 


\title{
Review of
}

\section{Talking About Feelings and Values with Children}

by Michael Schleifer (with Cynthia Martiny), Calgary, Alberta: Detselig, 2006

\author{
THOMAS FALKENBERG \\ University of Manitoba, Canada
}

Talking About Feelings and Values with Children is a book on moral education directed toward those who educate and raise children, in particular young children. The moral education approach the authors suggest in their book is characterized by three core features. ${ }^{1}$ First, the approach is grounded in Aristotelian virtue ethics. Second, the authors address the need for helping children develop judgment that arises from an Aristotelian virtue ethics by suggesting that educators (and that includes parents) engage in dialogue with children about feelings and values. Third, the authors see judgment and emotions as being inextricably linked in human moral functioning in two ways: (i) emotions are moral and as such are subject to moral judgment; (ii) emotions are a form of (moral) judgment and are, thus, integral to moral living. In the following I take a closer look at these three features.

What a reader of this book will notice in connection with the first core feature is that the authors use the term "values" where in the Aristotelian tradition one would use "virtues". The authors - for the most part - seem to even go so far as to not distinguish between the two terms: "There are very few rules about honesty, or at least very few simply organizing rules that tell the story. We do want this moral virtue in our children, and so it is an important moral value to discuss" (p. 60; my emphasis; see also the interchangeable use of both terms on p. 39). It is not until three quarters into the book that the authors provide a conceptual connection between their notion of virtue and value: "A virtue is a human excellence whose possession tends to enable, facilitate, promote, express, honor, and appreciate a value." (p. 107) After then pointing out that in the history of thinking about virtues a variety of authors like Aristotle, Plato, Aquinas, Nietzsche, and Confucius have suggested a "hodgepodge of virtues" (p. 108), the authors suggest that "we must concentrate not on the specific content of the virtues and vices, but on the spirit of Aristotle's analysis" (p. 108), which I take to read that what is central in moral living is moral judgement and, thus, dialogue about values as a way to develop moral judgment.

I can see great benefit in the use of "values" rather than "virtues" in these times of giving preference to a particular type of character education in North America. According to this type of character education, virtues are what people "have" or "have not" or may have to a certain degree, and there is a common understanding of what those virtues are that people should have; the task of virtue education, then, is to inculcate those virtues. The approach the authors take in their book, however, is somewhat different. At the centre of their notion of a moral person is good (moral) judgment. They

\footnotetext{
${ }^{1} \mathrm{I}$ am not suggesting that the authors see their approach to talking about feelings and values with children as a complete approach to moral education, though I do suggest that their approach is an approach that is intended to contribute to central aspects of the moral development of children.

(C) Copyright 2006. The author, Thomas Falkenberg, assigns to Paideusis the right of first publication and educational and nonprofit institutions a non-exclusive license to use this document for personal use and in courses of instruction provided that the article is used in full and this copyright statement is reproduced. Any other usage is probibited without the express permission of the author.
} 
suggest honesty, politeness, responsibility, and so on more as value categories according to which human thinking, conduct and feeling can be categorized. In this approach, such categorization is then debated and discussed in a dialogue: which type of thinking, conduct and feeling and which particular concrete instantiation of such a type belongs into the respective value category? "What is politeness?", "When is it okay to lie?" and "Is it appropriate to blame your brother in this situation?")

Such dialogues are at the heart of the moral education approach the authors suggest: discussing values helps develop good (moral) judgment (chapter 2). It seems to me that the authors shortchange their approach when they put their book in line with the character education approach I just referred to: "Other books, some very excellent ones [and they refer here to books on character education I just talked about], focus on moral education, discipline, character training, and communication skills. What the present book offers, in addition to these important dimensions, is a focus on dialogue" (p. 19, emphasis in original). The authors' focus on dialogue as a means of developing judgment in order to cultivate moral agency is less an addition to the line of those other books; rather, it provides quite a different perspective on what moral education is about, and, thus, the authors provide a different perspective on morality. Approaches like Michelle Borba's (2001) Building Moral Intelligence - one of the "other books" Schleifer and Martiny are referring to - conceptualize moral education from the point of view of a "moral crisis" in society, approach morality as a matter of "good character", identify "good character" with having generalized virtues (understood as character traits), take a clear stance on moral issues and are highly certain about the adequacy of that stance, and, finally, suggest and promote a direct teaching approach to the inculcation of the chosen generalized virtues (see, for instance, the direct intervention strategy explicit in the example of a parental intervention in Borba, 2001, p. 78). Schleifer and Martiny, on the other hand, define morality as being "concerned with what an individual ought personally to do in situations that typically involve inner conflict" (p. 26), and as such, adults' concern for children's moral development is more grounded in the human condition - human life being full of situations of inner conflict - than in a response to a "moral crisis" in society. Furthermore, as mentioned above, the authors ground moral education in developing good judgment to deal with such inner conflict rather than in inculcating particular stances on moral questions. To illustrate the sharp difference in perspectives, Borba (2001, p. 53, my emphasis) explains in a summarizing overview that "people with a conscience . . . do not steal, cheat, or lie, because they know it's wrong". For Schleifer and Martiny, on the other hand, honesty is a moral value that needs inquiry, and so they discuss questions like "What is lying?" and "Is it always wrong not to say the truth?", as well, they discuss humor and sarcasm in connection with honesty, thus helping children understand moral concepts, their role in their own and other people's lives, and the subtleties with which such concepts can play that role (chapter 3). Schleifer and Martiny want to help children deal with the complex social world intelligently when inner conflict about what one might want to do or is inclined to do and what one "ought" to do. Understanding and good judgment within a given domain of human experience seem to be the central characteristics for intelligent human functioning within that domain. Since Schleifer and Martiny's dialogical approach aims at developing understanding and good judgment in the domain of human moral functioning, it seems to me that it is their approach that deserves much more to be characterized as developing "moral intelligence".

For Schleifer and Martiny, part of helping children develop "moral understanding" is that they experience limits of moral possibilities set by the adults around them: "Educators will, of course, may want to make use of whatever discipline or control is needed in such cases [of aggressive behavior]. However, one should always offer an explanation of why hitting, pushing, or spitting at another child is wrong" (p. 87). This approach of having children experience limits of moral possibilities is still within the idea of developing "moral intelligence" in children, but it might be here where Talking About Feelings and Values with Children deviates from Aristotle's approach to moral education of children, especially very young children. While Schleifer and Martiny argue that "instilling habits in young children without offering explanation is not a good idea" and that "moral values left unexplained and undiscussed are worse than no moral values at all" (p. 17), Aristotle argues that habituation of doing virtuous acts in early 
years is a prerequisite for using the Doctrine of the Mean to live a virtuous life, because early habituation prepares in people the required "affinity to virtue": "As a piece of land has to be prepared beforehand if it is to nourish the seed, so the mind of the pupil has to be prepared in its habits if it is to enjoy and dislike the right things" (Aristotle, trans. 1976, 1180b24-26; see also 1104b11-13). Although Schleifer and Martiny do not seem to quite share my view of their approach deviating from Aristotle's view of the matter (p. 17), I see in their approach a clear shift in emphasis away from habituation (training) in early years to one of developing moral understanding (judgment) through dialogue. The optimism this approach of developing moral understanding suggests for developing students' moral agency - an optimism that is not shared by Aristotle to this degree - is grounded in the authors' belief that "children are already naturally kind, not cruel" (p. 85). Helping children to understand how their decisions and conduct affect other people and themselves in terms of developing, sustaining, and enhancing kind (caring) relationships with others should then lead "naturally" to "good moral conduct" by children.

Forming good (moral) judgment is at the centre of the authors" concern, because "all we can do is help provide our children with good judgment. The choice will be theirs!" (p. 15; quote in italics in original). Consider the famous quote by Aristotle.

It is easy to get angry - anyone can do that - or to give and spend money; but to feel or act towards the right person to the right extent at the right time for the right reason in the right way - that is not easy. (Aristotle, trans. 1976, 1109a26-29).

In this quote - a central statement in his Nichomachian Ethics (NE) - Aristotle provides us with a challenge to ethical living: being able to judge the situational adequacy of our emotional (feeling) and physical (acting) responses. This quote can serve as a motto to Schleifer and Martiny's book for several reasons. First, the authors refer to the quote themselves to pinpoint their ethical perspective (pp. 39, 105). Second, it connects values and virtues with emotions by making emotional responses - or better, responses to felt emotions - a moral or ethical issue. ${ }^{2}$ Third, it exemplifies Aristotle's Doctrine of the Mean, which states that moral virtue is a mean between two vices, one of excess and the other of deficiency (NE, 1106a14-1109b27). Throughout the book the authors adopt this principle in their own approach to values and feelings, although they do not explicitly refer to Aristotle's Doctrine. Here is one example: "Generosity, however, like every other moral virtue, can be too extreme. A child who gives everything away (like the corresponding adult) is as bad as one who never shares at all. Too much or too little is to be avoided. Our judgment will be called into play, therefore, to determine what the happy balance is, where the moderation lies." (pp. 92-93)

The quote by Aristotle above suggests that he sees emotions as an integral part of human moral functioning, and so do Schleifer and Martiny. Following Aristotle and Nussbaum (2001), the authors conceptualize emotions as "a form of judgment" (p. 96), according to which our emotional response in a given situation is a judgment about the respective state of affairs that gave rise to the emotion. Feeling fear in a situation, for instance, expresses that we have judged the situation as dangerous. As the authors point out, conceptualizing emotions as moral judgments is not the only way in which emotions have been conceptualized in the literature, but research on the emotional brain has strongly supported their view, as the references in the book demonstrate.

\footnotetext{
${ }^{2}$ It is interesting to note that the quote the authors provide - for which they do not give a reference - does not include the reference to "feeling" as the translation I have used. Their quote reads (p. 39): "Anyone can become angry - that is easy. But to be angry with the right person, to the right degree, at the right time, for the right purpose, and in the right way - this is not easy." Although another translation of the Nicomachean Ethics (Aristotle, trans. 1941) also does not include a reference to "feeling", I preferred the translation I have used, because it captures more explicitly the involvement of judging one's feeling in moral living - a central point in Talking About Feelings and Values with Children.
} 
Emotions, as an integral part of human moral functioning, are moral judgments, and as such they are subject to the already adopted Aristotelian Doctrine of the Mean: "The key point is that one must show the emotion, but not too much and not too little" (p. 107). This view of emotions as being subject to the Doctrine of the Mean has implications for moral education, because finding the mean is a matter of good judgment. The authors suggest that good judgment in showing emotions at the level just right for the given situation, the persons involved, and so on, involves two things: recognizing emotional states in other people and being able to control one's own emotional states. Thus, in a fashion parallel to the authors' approach to developing good judgment on values, helping children develop emotional judgment is best done by helping them understand emotions - their own as well as others' - by talking with children about emotions. Being intelligent about human emotions guided by the Doctrine of the Mean provides for recognition and control in the emotional realm and is at the core of human moral functioning as envisioned by the authors.

The Doctrine of the Mean is so central to the moral education approach suggested in Talking About Feelings and Values with Children, that I think it is important to discuss a danger that I see in the practical use of this Doctrine and which I think the authors do not seem to outline sufficiently - maybe because they might not share this concern with me. I want to discuss the concern by starting out with a quote I used above and which reflects the book's use of the Doctrine in the discussion about generosity as a moral value: "A child who gives everything away (like the corresponding adult) is as bad as one who never shares at all." (p. 92) Within our cultural context it might be seen as a sign of maladaptation by a child if he or she gives everything away, but for a Buddhist monk to have given away his possession and to live on alms can generally not be considered being "bad", because the monk might live quite a happy and fulfilling life and also contribute to the well-being of his community. Aristotle understands the mean as a relative mean, namely relative to the individual moral agent (NE, 1107a1). With the potential for a much greater understanding of the great variation in cultural patterns than Aristotle might have had in his time, we should be careful not to overlook how our cultural embeddedness frames our very understanding of what "the extremes" are and, thus, what the mean is we should aim for in our attempt to live a Aristotelianly virtuous life.

There will probably be a few smaller challenges a reader of Talking About Feelings and Values with Children will face with respect to the just discussed three features of the moral education approach in the book. First, the authors argue vehemently against moral relativism (pp. 26-30) and talk about imparting universal values (p. 32), but then, on the other hand, they write, following the Aristotle quote cited above: "We can, in the twenty-first century, paraphrase Aristotle by substituting the moral values and emotions, which we find important. For the word 'anger' in the above quote [by Aristotle], we can substitute our own values." (p. 39). Second, on the one hand the authors emphasize that "all we can do is help provide our children with good judgment. The choice will be theirs!" (p. 15), but on the other hand they talk about "imparting universal values" (p. 32). Third, the authors refer to a consensus on certain values as universal values (p. 32), a consensus on the definition of judgment (p. 35) and a consensus on the notion of virtue (p. 107). In any of these three cases there should be great doubt about the existence of such a consensus. Fourth, at the beginning of chapter 5 , the authors talk briefly about "the ethics of caring", and write: "Moral education programs, dissatisfied with an emphasis on reasoning and moral dilemmas, have insisted on teachers providing a perspective which has been called 'relations ethics." In the same paragraph, however, they provide "an example of one of these new 'caring' situations discussed in schools" (p. 85) which is designed exactly as a moral dilemma problem to be solved - except that now the rational given might refer to the importance of personal relations rather than (Kohlbergian) moral principles. One of the central concerns about the dilemma approach in moral education raised by Noddings (1984, pp. 94-95), the most prominent proponent of an ethic of care in education, has always been that those problems are artificial, abstract, and not considerate of the particularities of a given needs situation.

Talking now about the book in more general terms, the main part of Talking About Feelings and $V$ alues with Children is well structured into four parts, an introduction and one interlude, the latter being 
placed between the second and third chapter. Following the introduction, the first part outlines the notion of "values". The second part deals with the talking about the three (as the authors claim) "universal" values: honesty, politeness, and responsibility. The third part deals with feelings: empathy and caring, understanding emotions, and how emotions and morality relate. Part four, finally, looks at talking about "the most difficult subjects": separation, illness, touching and (religious) beliefs. In addition, the book has 14 appendices, each consisting of material that the reader can use to engage in talks about values and emotions with children. Many of the materials are taken from novels and manuals of the Philosophy for Children approach promoted at the Institute for the Advancement of Philosophy for Children at Montclair University (http://www.montclair.edu/page/cehs/academic/ iapc). ${ }^{3}$ Each part of the book is divided into several chapters. There are 12 chapters and each chapter is subdivided into smaller sections, most of which are less than one page long. The book also includes an annotated list of recommended readings on different topics connected with the theme of the book. ${ }^{4}$

Talking About Feelings and Values with Children is not written to make an original contribution to the philosophical thinking on ethics or psychological understanding of emotions and moral development, but, rather, as the authors tell the reader on different occasions (e.g., p. 19), to synthesize already existing philosophical thinking and psychological understanding around emotions and morality and what it implies for the moral education of young children. (The main author, Michael Schleifer, has himself contributed to both fields of study as is documented in the extensive literature references in the endnotes.) As such, the book has the potential to contribute greatly to bridging the gap that often exists between those works produced in the dust-free academic ivory tower and the works needed for the dusty, messy roads of human social living in general and education in particular.

The book's targeted audiences (p. 13) are university students enrolled in an early childhood program, and professional educators, as well as parents (and grandparents, as the authors note). The clear structure and the detailed table of contents will allow these audiences to use the book as a "handbook" for their talking about feelings and values with children. The book itself is not a how-to book on moral education as, for instance, Borba (2001) is, although some concrete how-to recommendations can occasionally be found, as for instance, in the recommendation on "the development of empathy" (p. 89). The great contribution I can see this book making in bridging academic and practical concerns around moral education is by doing exactly what it argues educators, parents, grandparents, and others should consider in their talking about feelings and values with children: Talking About Feelings and Values with Children is written in a way that engages its readers (the adults) in a dialogue about such talking, and philosophical and psychological concepts and ideas around values, emotions, and moral education. Reading the book is moral education in the sense suggested in the book: developing good moral judgment by engaging in an (internal) dialogue about values and emotions. Many subsection headers in the book are questions, and those sections invite the reader to engage in a dialogue (to the degree reading a book allows for that) about those questions and the ideas behind them. The book is at its strongest where it invites the reader to think about talking about feelings and values with children; it is at its weakest where it tells how things are and what is to be done. Fortunately, the former by far outweigh the latter.

For a "how-to" practitioner there might be too much theoretical discussion in the book, while for the theoretical philosopher there might be too little in-depth discussion of the issues; in other words - applying Aristotle's Doctrine of the Mean - the book could have just the right balance for the

\footnotetext{
3 This reference is unfortunately missing.

${ }^{4}$ There are also 312 (!) endnotes, most of which consist of references and unusually rich lists of additional literature on the respective issue. What is somewhat irritating in terms of practical use is that the endnotes are placed before the lengthy appendix and that they are endnotes in the first place, rather than footnotes. (I am wondering whether there is still any cost-saving necessity to the preference of endnotes over footnotes for the publisher in this age of technological advancement.)
} 
reader's educational praxis. Would I recommend the book to those primary school student teachers I teach? I already did.

\section{References}

Aristotle (1941). Ethica Nicomachea (W. D. Ross, Trans.). In Richard McKeon (2001, Ed.), The basic work of Aristotle (pp. 927-1112). New York: The Modern Library.

Aristotle (1976). The ethics of Aristotle: The Nicomachean Ethics (rev. ed.; J. A. K. Thomson, Trans.). London: Penguin Books.

Borba, Michelle (2001). Building moral intelligence: The seven essential virtues that teach kids to do the right thing. San Francisco: Jossey-Bass.

Noddings, Nel (1984). Caring: A feminine approach to ethics \& moral education. Berkeley, CA: University of California Press.

Nussbaum, Martha C. (2001). Upheavals of thought: The intelligence of emotions. Cambridge: Cambridge University Press. 